\title{
THE PAPACY AND BYZANTIUM IN THE SEVENTH- AND EARLY EIGHTH-CENTURY SECTIONS OF THE LIBER PONTIFICALIS
}

\author{
by Rosamond McKitterick
}

The Liber pontificalis, the serial biography of the popes running from Saint Peter to the end of the ninth century, first compiled in Rome during the 'Gothic Wars' in the sixth century and continued at various stages in the next three centuries, offers a distinctive narrative of the history of Rome and of the papacy in the early Middle Ages. This paper argues that the seventh-and early eighth-century sections, too often simply mined for nuggets of information about church buildings, represent the pope in a particular way both in relation to Byzantium in theological and political terms, and as the successor to Saint Peter in Rome. The papal narrative undermines the usual assumptions about the so-called 'Byzantine Reconquest' and the Roman perception, if not the reality, of the degree to which 'Byzantine rule' was exercised in Italy between the middle of the sixth and first half of the eighth century. Lastly, these 'continuations' have important implications for any interpretation of the purpose and construction of the Liber pontificalis, and of its dissemination beyond Rome in the seventh and eighth centuries.

Il Liber pontificalis, raccolta di biografie dei papi da San Pietro alla fine del IX secolo, redatto per la prima volta a Roma durante le Guerre Gotiche nel VI secolo e continuato in vario modo nei successivi tre secoli, offre un racconto peculiare della storia di Roma e del papato nell'Alto Medioevo. Nel presente lavoro si sostiene come le sezioni relative al VII e all'inizio dell'VIII secolo, troppo spesso utilizzate semplicemente per desumere informazioni preziose sugli edifici delle chiese, rappresentino il papa in un modo particolare sia in relazione a Bisanzio in termini teologici e politici sia come successore di San Pietro a Roma. La narrazione relativa ai papi mina le comuni affermazioni relative alla cosiddetta riconquista bizantina e la percezione, se non la realtà, romana del livello in cui la 'regola Bizantina' era esercitata in Italia tra la metà del VI e la prima metà dell'VIII secolo. Infine, queste 'continuazioni' hanno importanti implicazioni per qualsiasi interpretazione del fine e delle modalità di costruzione del Liber pontificalis e della sua diffusione al di fuori di Roma nei secoli VII e VIII.

The Life of John VII (1 March 705-18 October 707) in the Liber pontificalis Life 88 begins with the information that John was of Greek origin, the son of Plato, that he held the see two years, seven months and seventeen days, and was a man of great learning and eloquence. ${ }^{1}$ The entry also includes the famous reference to the church of Santa Maria Antiqua in the Forum in Rome: 'He

1 Johannes natione Grecus, de patre Platone, sedit ann. II mens. VII dies XVII. Vir eruditissimus et facundus eloquentia. On the use and meaning of the portmanteau term Graecus in early medieval Rome see C. Gantner, 'The label "Greeks" in the papal diplomatic repertoire in the eighth century', in W. Pohl and G. Heydemann (eds), Strategies of Identification: Ethnicity and Religion in Early Medieval Europe (Cultural Encounters in Late Antiquity and the Middle Ages 13) (Turnhout, 2013), 303-49, and further C. Gantner, Freunde Roms und Völker der Finsternis: Die 
adorned with painting the basilica of the holy mother of God which is called Antiqua and there he built a new ambo, and above the same church an episcopium which he wanted to build for his own use, and there his life and the time of his pontificate came to an end.'2 Another instance of John's honouring of the cult of Mary was the oratory he built in Saint Peter's basilica, and the work he commissioned for the basilica of Saint Eugenia and the cemeteries of the martyrs Marcellian and Mark and of the pontiff Saint Damasus. An apparently snide comment is then added: 'he also provided images in various churches; whoever wants to know what he looked like will find his face depicted on them'. ${ }^{3}$

All this might be thought to serve as a sufficient account of the pope's career, but a second section of the Life, chapters 3-5, was added. This looks like the work of a different author, perhaps dissatisfied with the first attempt. He introduced the extra historical information about King Aripert of the Lombards' restoration of the Cottian Alps (recorded in a charter written in gold letters), the restoration of Justinian II to his throne, how Justinian sent John copies of acts he had previously sent to Pope Sergius, and how John, 'terrified in his human weakness, sent them back to the prince by the same metropolitans without any emendations at all' (Sed hic, humana fragilitate timidus, hos nequaquam emendans per suprafatos metropolitas direxit ad principem). ${ }^{4}$

The content, tone and structure of the Life of John VII, the possible augmentation of the narrative by a second author, the choice of detail about the

Konstruktion von Anderen im päpstlichen Rom des 8. und 9. Jahrhunderts (Vienna/Cologne/ Weimar, 2014), 60-136.

2 Liber pontificalis, ed. L. Duchesne, Le Liber pontificalis. Texte, introduction et commentaire, 2 vols (Paris, 1886-92, repr. 1955), I, Life 88, 385; English translation R. Davis, The Book of Pontiffs (Liber Pontificalis): The Ancient Biographies of the First Ninety Popes to AD 715, third edition (Liverpool, 2010), 86 (hereafter cited as LP I; trans. Davis): Basilicam itaque sanctae dei genetricis qui antiqua vocatur, pictura decoravit illicque ambonem noviter fecit et super eandem ecclesiam episcopiam, quantum ad se construere malluit, illicque pontificatus sui tempus explevit. On Santa Maria Antiqua see E. Rubery and G. Bordi (eds), Santa Maria Antiqua (Turnhout, forthcoming).

3 LP I, Life 88, c. 1, 386: Hic fecit oratorium sanctae dei genetricis intro ecclesiam beati Petri apostoli, cuius parietes musibo depinxit, illicque auri et argenti quantitatem multam expendit, et venerabilium patrum dextra levaque vultus erexit. Hic restauravit Basilicam sanctae Eugeniae, qui longo per tempore distecta atque diruta fuerat. Laboravit autem et in cymiteriis beatorum martyrum Marcelliani et Marci Damasique sancti pontificis. Fecit vero et imagines per diversas ecclesias, quas quicumque nosse desiderat, in eis eius vultum depictum repperiet; trans. Davis, 86. One of these images, with a square halo, is preserved in the Vatican grottoes under the present basilica of Saint Peter, reproduced with discussion of the original oratory in which it was placed in A. Ballardini and P. Pogliani, 'A reconstruction of the Oratory of John VII (705-7)', in R. McKitterick, J. Osborne, C.M. Richardson and J. Story (eds), Old St Peter's, Rome (British School at Rome Studies) (Cambridge, 2013), 190-213 at fig. 10.10, p. 208. On the Palatine see A. Augenti, 'Continuity and discontinuity of a seat of power: the Palatine hill from the fifth to the tenth century', in J.M.H. Smith (ed.), Early Medieval Rome and the Christian West: Essays in Honour of Donald A. Bullough (Leiden, 2000), 43-54.

4 LP I, Life 88, c. 5, 386; trans. Davis, 86-7. 
pope's activities as a patron and builder of churches, and his allegedly pusillanimous response to the Byzantine emperor Justinian II's request for endorsement and return of the Acta of the Quinisext Council of 692, all prompt questions similar to those raised by the entries for each pope in the seventh- and early eighth-century portions of the Liber pontificalis. The way in which the separate Lives of each pope in the Liber pontificalis characterize the spectrum of relations with Byzantium and the particular portrayal of each pontiff have to be set within a larger consideration of the composition and transmission of the Liber pontificalis. Quite apart from the validity of the historical information the Liber pontificalis authors chose to include, and the significance of the omissions, I wish to suggest that Lives 60-90 of the Liber pontificalis, the narrative for the period 536-715, need to be divided into sections or 'continuations' which correspond to specific phases of compilation. Together, these offer a distinct and distinctive demonstration, and assertion, of the position of the pope. First of all the pope is represented in a particular way in relation to Byzantium in both theological and political terms. Secondly, he is bishop of Rome, successor to Saint Peter, the first among the patriarchal sees, and all that that could imply. Lives 60-90 of the Liber pontificalis, moreover, have the potential to undermine the usual assumptions about the so-called 'Byzantine Reconquest' and the Roman perception, if not the reality, of the degree to which 'Byzantine rule' was exercised in Italy between the middle of the sixth and first half of the eighth century. ${ }^{5}$ Lastly, Lives 60-90 have important implications for the construction and dissemination of the narrative beyond Rome.

To demonstrate this it is necessary to examine the construction and content of these 'continuations' of the Liber pontificalis. Thereafter I shall discuss the light the manuscript dissemination of the Liber pontificalis may shed on their composition. A consideration of both production and dissemination may then contribute to our understanding of the Liber pontificalis' contents, the Liber pontificalis' value as historical evidence for the perception within Rome of the pope's role, and the text's overall function.

\section{WHO WROTE THE LIBER PONTIFICALIS?}

An important consideration throughout the Liber pontificalis is of course authorship and the degree of official status it enjoyed. Unfortunately there is no certainty or agreement about either, though it is generally agreed that the authors were papal administrators or 'civil servants' of some kind. Some, such

\footnotetext{
5 For the context of this discussion see in particular T.F.X. Noble, 'Rome in the seventh century', in M. Lapidge (ed.), Archbishop Theodore (Cambridge, 1995), 68-87; C. Cubitt, 'The Roman perspective', in R. Price, P. Booth and C. Cubitt, The Acts of the Lateran Synod of 649 (Translated Texts for Historians) (Liverpool, 2014), 40-58; and C. Gantner, 'The eighth-century papacy as cultural broker', in C. Gantner, R. McKitterick and S. Meeder (eds), The Resources of the Past in Early Medieval Europe (Cambridge, 2015), 245-61.
} 
as Louis Duchesne and Herman Geertman, have suggested that it was the clerics in the vestiarium itself who composed the papal lives, though Duchesne conceded the possibility that responsibility may have moved within the papal offices for the later sections. ${ }^{6}$ Thomas Noble preferred to see the text as emerging from the notarial office of the primicerius notariorum, who made use of papal records in other offices, especially that of the vestiarius. ${ }^{7}$

The efforts to decide in favour of one or the other office on the grounds of the inclusion of references to a particular individual are not conclusive. Certainly Life 96 (Stephen III) includes the career of the primicerius Christopher, but Life 97 (Hadrian I) refers to Hadrian assigning the restoration of Saint Peter's and Saint Paul's to his trusty vestiarius Januarius. ${ }^{8}$ The famous reference in Life 94 (Stephen II), c. 24 to the death of the primicerius Ambrose at Saint Maurice d'Agaune when he was part of Pope Stephen's entourage in Francia is a later interpolation in the Frankish recensions. The remarkable epitaph of Ambrose from Old Saint Peter's, preserved by Tiberio Alfarano, and offering the story of the bringing of Ambrose's body back to its proper resting place after six year's exile in Francia, unfortunately only praises his learning and virtues in general terms. ${ }^{9}$ The singling out of individuals, therefore, does not appear to strengthen the case for assigning the authorship of the Liber pontificalis to one or other office within the papal administration. François Bougard proposed some movement between the two offices by those responsible for the later sections of the Liber pontificalis' composition, whether in terms of actual responsibility or merely to gain access to useful documents, papal letters, imperial mandates, archival copies of conciliar acta, registers of repairs or embellishments to buildings, notes of church furniture or the like. They may after all have been working in the same room or in close proximity in the Lateran palace at least. ${ }^{10}$ That the authors occasionally had to consult other texts to compile their accounts can hardly be doubted, but we only have the final result to help us establish the process of composition.

6 LP I, clxii, and compare on the later sections L. Duchesne, Etude sur le Liber pontificalis (Paris, 1877), 205-9; H. Geertman, 'Documenti, redattori e la formazione del testo del Liber pontificalis', in H. Geertman (ed), Il Liber pontificalis e la storia materiale (Mededelingen van het Nederlands Instituut te Rome 60-1) (Assen, 2003), 267-84, repr. in H. Geertman, Hic fecit basilicam. Studi sul Liber pontificalis e gli edifici ecclesiastici di Roma da Silvestro a Silverio (Leuven, 2004), 149-68. See also H. Geertman, 'La genesi del Liber pontificalis romano: un processo di organizzazione della memoria', in F. Bougard and M. Sot (eds), Liber, gesta, histoire. Écrire l'histoire des évêques et des papes, de l'Antiquité au XXIe siècle (Turnhout, 2009), 37-108 and H. Geertman, More veterum. Il 'Liber Pontificalis' e gli edifici ecclesiastici di Roma nella tarda antichità e nell'alto medioevo (Groningen, 1975), 34.

7 T.F.X. Noble, 'A new look at the Liber pontificalis', Archivium Historiae Pontificiae 23 (1985), 347-58.

$8 \quad$ LP I, Life 97, c. 5, 441.

9 LP I, Life 94, cc. 23-4, 457-8 n. 27.

10 F. Bougard, 'Composition, diffusion et réception des parties tardives du Liber pontificalis romain (VIIIe-IXe siècles)', in Bougard and Sot (eds), Liber, gesta, histoire (above, n. 6), 127-52. 
The most pertinent recent contribution to this question of the evidence for authorship is the remarkable study of the use of cursus or Latin prose rhythm in the papal chancery carried out by Richard Pollard, which has been augmented by a further investigation of the authorship of Pope Gregory's letters. ${ }^{11}$ From his analysis of the use of prose rhythm in papal letters from Pelagius II to John VII, Pollard has established that cursus continued to be used by papal notaries for papal letters until at least the end of the seventh century, and was particularly strong under Popes Pelagius II, Gregory I and Boniface V. There is a marked drop during the pontificate of Martin I and Vitalian, but a return under Adeodatus, Agatho and Leo II. Few letters of Sergius I survive, so, despite a strong use of cursus in the small group of extant letters, there is not a sufficient number to establish continuity. Cursus was on the wane during the pontificate of John VI. Pollard then tested the Liber pontificalis for use of Latin prose rhythm in the Lives from Vigilius to Deusdedit (537-618), that is, the period when cursus was in full use in the papal scrinium. But in these Lives at least there is very little use of cursus and the style and forms are entirely different from those of the papal letters. In the late sixth and early seventh centuries, therefore, whoever wrote the papal letters had apparently no role in writing the Liber pontificalis, though it is conceivable that use or not of cursus may have been a matter of individual choice, rather than habitual or unconscious as a result of early training. The notaries and papal letter-writers may have decided to do so later, or taken over the responsibility for the Liber pontificalis, but the necessary stylistic analysis that may help to distinguish among the authors of Liber pontificalis and of the papal letters in the course of the seventh century has still to be done. Cursus itself was no longer used in the papal chancery in the eighth century. In a further exploration of the relationship between the Liber pontificalis and the papal letters gathered together in the Codex epistolaris Carolinus, however, Richard Pollard has established that the Liber pontificalis authors between 700 and 750, especially the author of the Life of Gregory III, had some experience of rhythmic prose, but that those responsible for the letters of the popes in this same period did not use cursus. ${ }^{12}$

We are therefore left for the moment with papal administrators of some kind as the authors of the Liber pontificalis, but with an indication of a division of responsibilities within the papal administration. It is also possible that some individuals wrote more than one Life. In the eighth century, for instance, a single author wrote Lives 95 (Paul I, †767), 96 (Stephen III, †772) and the first part of 97 (Hadrian I, 774-95), so there is no reason why this should not also

11 R. Pollard, 'The decline of cursus in the papal chancery', Studi Medievali, 3rd series, 50 (2009), 1-40, esp. pp. 28-31 and R. Pollard, 'A cooperative correspondence: the letters of Gregory the Great', in B. Neil and M. dal Santo (eds), A Companion to Gregory the Great (Leiden, 2013), 291-312.

12 R. Pollard, 'The Latin of the Codex epistolaris Carolinus', in R. McKitterick, R. Pollard and D. van Espelo, The Codex Epistolaris Carolinus (Translated Texts for Historians) (Liverpool, forthcoming). 
have been the case in the seventh century. ${ }^{13}$ Ann van Dijk, furthermore, has suggested that the same author might be responsible for the Lives of Sergius I and John VII. ${ }^{14}$ It is also possible that more than one author attempted to write the biography of a particular pope. I have already mentioned the possibility that we have two attempts at the Life of John VII amalgamated into one. The Life of Stephen II (Life 94) survives in no fewer than three different versions, ${ }^{15}$ and two authors, one following the other, were responsible for the Life of Hadrian I (Life 97), though this phenomenon may be peculiar to the eighthand ninth-century sections rather than to an earlier stage in the text's composition.

'Who wrote the Liber pontificalis?' is thus certainly a necessary question, even if it cannot be answered either simply or definitively. A full stylistic analysis may yield further information in due course. If indeed the authors were the personnel of one or the other of two different offices within the papal administration then, to state the obvious, there is no necessity to assume that the view disseminated of a particular pope is bound to be uncritical. The opinions are more likely to be those of the officials working for any one pope's successor. The negative presentations of John VII being too frightened to amend the acta sent by the emperor, referred to at the beginning of this paper, need to be seen in this light. So does the remarkable account of the election and violent deposition of Pope Constantine II. ${ }^{16}$ Yet immediate comments about individual popes also need to be set within the context of the composition and compilation of the larger work, its intentions as a whole, and the processes of its dissemination, for it is manifestly clear that the composition as a whole could accommodate the failings of particular bishops of Rome. It is for this reason that I want here to address the Liber pontificalis Lives 60-90, and the themes therein which emerge, in the light of the pattern already set by the first section (Lives 1-59). The internal evidence presented by the text itself may enable us to identify the purpose of the Liber pontificalis in the form in which it was refocused and disseminated by the compilers and authors of the seventh- and early eighth-century sections.

\section{THE FIRST SECTION OF THE LIBER PONTIFICALIS AND THE FIRST CONTINUATION}

The Liber pontificalis runs from Saint Peter to Pope Stephen V, the 112th bishop. Organized in a new Petrine chronology, details of the pope's name, origin or natio

13 R. Davis, The Lives of the Eighth-Century Popes (Liber Pontificalis) (Translated Texts for Historians) (Liverpool, 1992), 85.

14 A. van Dijk, 'Visual diplomacy in the Apsidal Arch of Santa Maria Antiqua', in Rubery and Bordi (eds), Santa Maria Antiqua (above, n. 2).

15 C. Gantner, 'The Lombard Recension of the Roman Liber Pontificalis', Rivista di Storia del Cristianesimo 10 (2013), 65-114.

16 R. McKitterick, 'The damnatio memoriae of Pope Constantine II (767-768)', in R. Balzaretti, J. Barrow and P. Skinner (eds), Italy and Medieval Europe: Papers for Chris Wickham on the Occasion of his 65th Birthday (Past and Present Supplementary Series) (Oxford, forthcoming). 
and father, the length of his reign and the length of vacancy before the next bishop are the almost constant formulaic elements. The names of the secular rulers of the time (emperor and/or consuls, and, for Lives 50-8 [Felix III-John II], the Ostrogothic ruler and the emperor $)^{17}$ are introduced in the first section of the Liber pontificalis with the formula fuit autem temporibus, with notable absences in Lives 22 (Cornelius), 38-49 (Felix II-Simplicius) and 59 (Agapitus). This formula and the imperial names are not invoked from the Gothic War period onwards, that is, they do not occur at all in Lives 60-90 except in the final formulaic sentence in Life 86 recording the burial of Pope Sergius; only a handful of later ninth- and eleventh-century Frankish and Italian manuscripts interpolate a brief note for Lives 87-92 (and also for Lives 91 and 92), but that is to be attributed to later historical perceptions. The substance of the entries can vary considerably, presumably depending on the amount of information available, but normally the Lives include information about the pope's career before his elevation, his election, political actions, innovations, endowments, religious and legal practice, building activity, death, burial and the number of ordinations he performed of bishops, priests and deacons.

As is well known, the text was put together in stages. The first section from Saint Peter to Pope Agapitus was produced c. 535, though, as Geertman has suggested, this may have included the Life of Silverius. ${ }^{18}$ This itself is a slight adjustment of Duchesne's position. ${ }^{19}$ Mommsen was inclined to see the Liber pontificalis as first produced in the seventh century. The inspiration the Liber pontificalis provided Gregory of Tours for his summary history of the bishops of Tours in book X of his Histories is a clear indication, however, that this first section of the text had reached Gaul in some form by the end of the sixth century. ${ }^{20}$ The extant text of the Liber pontificalis appears to be a second edition, with echoes of a first edition surviving in the so-called Felician Epitome. This ends in $c .530$ with Life 56 (Pope Felix IV, 526-30). ${ }^{21}$

What is usually regarded as the first extension narrates the lives of the popes from Silverius or Vigilius to Honorius. The current understanding is that this continuation was added in the pontificate of Honorius, in the third decade of the seventh century

17 For Felix III only the names of Kings Odovacer and Theodoric are given: LP I, Life 50, c. 1, 252.

18 Geertman, 'La genesi del Liber pontificalis romano' (above, n. 6).

19 LP I, xxxiii-xlvii.

20 T. Mommsen, Liber pontificalis, pars prior (Monumenta Germaniae Historica, Gesta Pontificum Romanorum I) (Berlin, 1898), xvi and xxv, and compare L. Cuppo, 'I "pontifices" di Constantinopoli nel "Liber Pontificalis" del settimo secolo: note sul codice BAV, Vat. Lat. 3764', Rivista di Storia e Letteratura Religiosa 44 (2008), 359-71 and Gregory of Tours, Historiae X.31, ed. B. Krusch (Monumenta Germaniae Historica, Scriptores Rerum Merovingicarum I.1) (Hanover, 1951), 526-35. See also R. McKitterick, 'Rome and the popes in the construction of institutional history and identity in the early middle ages: the case of Leiden Universiteitsbibliotheek Scaliger MS 49', in O. Phelan and V. Carver (eds), Rome and Religion in the Medieval World: Studies in Honor of Thomas F.X. Noble (Aldershot, 2014), 207-34.

21 LP I, xlvii-liv. 
(625-38), or else in the pontificate of his successor Severinus. Raymond Davis suggested that the Life of Severinus contains what have been judged to be eyewitness accounts. Obviously such contemporary reports could be preserved and reproduced some time after the event, be recalled in old age, or even pretend to be eyewitness accounts. ${ }^{22}$ I shall return to the questions this section raises below. Thereafter the biographies may have been continued on a Life-by-Life basis (the usual assumption) or, more probably as I suggest below, in small batches, up to the end of the ninth century, by a variety of contemporary authors, mostly soon after the subject's death and on two occasions at least even while he was alive. Bede's reference to King Liutprand's gift of estates in the Cottian Alps to the pope in Life 91 (Gregory II, 715-31) in his Chronicle (c. 66 of the De temporum ratione), composed c. 725 , is the example usually cited in support of this view, though the Life of Zacharias also appears to have been completed within that pontiff's lifetime. Such precipitate composition may simply be a temporary innovation..$^{23}$ In any case the eighth-century portion after 715 presents special problems of its own, as do the Lives of the ninth century after Leo III. ${ }^{24}$

The pattern of authorship, as well as the hints in the extant manuscripts about their exemplars, therefore, may indicate the writing up and editing of single Lives or small groups of Lives. A number of Lives may have been drafted and assembled at particular stages and disseminated from Rome either in libelli or as part of an augmented entire text. ${ }^{25}$ Although the text's production may well have been in intensive periods of compilation and revision, the resulting text was distributed at specific moments in order to promote a particular political position.

As one way of exploring the questions raised by the continuations of the Liber pontificalis further, I suggest that it can be divided into sections as follows, with the date of composition and compilation of the portions of section II (A, B and C) left unspecified for the moment:

LP I (first redaction — surmised from the existence of early Epitomes F and K, ${ }^{26} c$. 530) Lives

1-56 Peter to Felix IV (†530)

LP I (second redaction, $c$. 535) Lives 1-59/?60 Peter-Agapitus (†536)/Silverius (†537)

LP IIA Lives 60-71 Silverius-Boniface V (†625)

LP IIB Lives 72-78 Honorius-Eugene I (†657)

LP IIC Lives 79-81 Adeodatus-Agatho; 82-90 Leo II-Constantine I (†715)

LP III Eighth-century Lives 91 (2 versions), 92, 93, 94 (three versions), 95, 96, 97 cc. 1-44, 97

cc. 45 to end Gregory II-Hadrian I (†795)

LP IV Ninth-century Lives 98-112 Leo III, Eugenius-Stephen V (†891).

22 Davis, Book of Pontiffs (above, n. 2), xlvii.

23 Bede, De temporum ratione, ed. T. Mommsen, Chronica minora III (Monumenta Germaniae Historica, Auctores Antiquissimi XIII) (Berlin, 1898), 326, under the year (since the Creation) 4670. $\mathrm{AD} 725$ is a terminus post quem, for it is the last date recorded in the De temporum ratione.

24 On the eighth-century Lives see especially Gantner, 'Lombard recension' (above, n. 15). On the ninth-century portions see the useful summaries by R. Davis, The Lives of the Ninth-Century Popes (Liber Pontificalis) (Translated Texts for Historians) (Liverpool, 1995).

25 See below, pp. 268-72.

26 On Epitomes $\mathrm{F}$ and $\mathrm{K}$ see $L P \mathrm{I}$, xlvix-lvii. 
The ideological, political and historiographical context in which the Liber pontificalis was first produced set an important precedent for the production of subsequent Lives. It cannot be stressed enough that the first section of the Liber pontificalis was composed against the backdrop of the Ostrogothic Wars of the middle of the sixth century, the Byzantine emperor's attempt to reincorporate Rome into the Eastern Empire, and the efforts of the bishops of Rome to establish their own authority within the city and as the spiritual leaders of the Christian world. Further, I have argued elsewhere that this first section of the Liber pontificalis offers a distinctively Christian presentation of the Roman past designed to change its audience's understanding of Roman history. Not only did the Liber pontificalis reshape the history of Rome by setting it within a new chronological framework from the time of Saint Peter; it also appropriated the original Roman historiographical genre of serial biography. The most influential models for the sixth-century compilers and authors were not the passiones of martyrs but rather the serial biographies of Roman emperors by Suetonius, Aurelius Victor, Eutropius, and above all the fourth-century Historia Augusta. The Liber pontificalis is Christian and Christianized Roman history. It constructs the popes as the rulers of Rome, replacing the emperors. ${ }^{27}$ It is thus a very particular response to the immediate political position of Rome in the fourth decade of the sixth century. ${ }^{28}$ Can the subsequent sections of the Liber pontificalis, especially those I identify as sections LP IIA (Lives 60-71 SilveriusBoniface V) and LP IIB (Lives 72-90 Honorius-Constantine I), be similarly connected with highly charged contexts of production? If they can, what might this suggest about the politics of the Liber pontificalis' content?

If we examine first of all what I have called LP IIA (first continuation), Lives 60-71 (Silverius-Boniface V AD 536-625), it is immediately apparent how sparing the details about the popes are in these twelve Lives. I summarize the contents very briefly in the schematic list below (where NNNL=name + natio + name of father + length of reign in years, month and days; and $\mathrm{DBOV}=$ death, burial, ordinations + length of vacancy before the next pope):

Life 60 Silverius NNNL; Gothic Wars; end of Witigis' rule in Italy; Silverius framed for treachery and exiled; DBOV

Life 61 Vigilius NNNL; career of Vigilius, Belisarius; arrival of Narses; Gothic rule ends in Italy; DBOV

27 R. McKitterick, 'Roman texts and Roman history in the Early Middle Ages', in C. Bolgia, R. McKitterick and J. Osborne (eds), Rome across Time and Space, c. 500-c. 1400: Cultural Translation and the Exchange of Ideas (Cambridge, 2011), 19-34. Some elements of this argument are to be found also in R. McKitterick, 'La place du Liber pontificalis dans les genres historiographiques du haut Moyen Âge', in Bougard and Sot (eds), Liber, gesta, histoire (above, n. 6), 23-35.

28 With a similar presumption of a particular impetus for composition see the argument for $c .500$ offered by D. Mauskopf Deliyannis, 'The Roman Liber pontificalis, papal primacy, and the Acacian Schism', Viator 45 (2014), 1-16; the overall emphasis on orthodoxy she rightly attributes to the Liber Pontificalis works just as well for the later date maintained here. 
Life 62 Pelagius I NNNL; Pelagius exonerates himself with liturgy on Narses' prompting; DBOV

Life 63 John III NNNL; Heruls and Franks; Narses; DBOV

Life 64 Benedict I NNNL; Lombards arrive; DBOV

Life 65 Pelagius II NNNL; Pelagius ordained without emperor's mandate; establishes monastery of Saint Hermes; Basilica of San Lorenzo; Lombard siege of Rome; DBOV

Life 66 Gregory I NNNL; books written; mission to English; church decoration and rededication of Sant'Agata dei Goti; DBOV

Life 67 Sabinian NNNL; famine in Rome; peace with Lombards; DBOV

Life 68 Boniface II NNNL; Saint Peter's head of all churches; papal election; DBOV

Life 69 Boniface IV NNNL; famine; flood; consecration of Pantheon to Mary the Virgin;

DBOV

Life 70 Deusdedit NNNL; earthquake; DBOV

Life 71 Boniface V NNNL; validity of a will secundum iussionem principis; ${ }^{29}$ clerical discipline and liturgy; cemetery of Nicomedes; DBOV

From this summary of the twelve Lives in this section it can be seen that personal details about the pope's actions as pope are absent. Catalogues of their building activities that are so striking a feature of the sixth-century Liber pontificalis from Peter to Agapetus are generally not included. Rare exceptions are the brief references in the Lives of Pelagius I, John III, Pelagius II, Gregory I and Boniface IV to the enhancement of particular martyrs' cults: the building of the basilica dedicated to Philip and James the apostle, the building of the basilica of San Lorenzo fuori le Mura and decoration of the shrine, the cemetery of Hermes 'the martyr', the enriching of the shrines of Saint Peter and Saint Paul, the rededication of the church of the Goths in the Subura to Saint Agatha the martyr, ${ }^{30}$ and the consecration of the Pantheon to Saint Mary and the martyrs respectively.

Further, the longer Lives at the beginning of section IIA, namely those of Silverius and Vigilius, are internally self-contradictory, especially in their attitudes to the elected pope. Thus a pope originally regarded as a quisling becomes a holy man and by implication after all a worthy successor of Saint Peter. Silverius (536-7) had been a candidate of Theodohad king of the Goths but, 'in order to safeguard the unity of the church and religion', the priests subscribed to Silverius after his ordination. He is subsequently framed for treachery, deposed and exiled, but then, because he is a confessor, 'the sick come to the place where he died in great numbers' and are cured. ${ }^{31}$

29 Davis, 65 translated this as 'in accordance with the emperor's mandate'.

30 LP I, Life 66, c. 4,312 . The rededication of a church to a different patron saint is not unprecedented. This has been misunderstood from Duchesne (LP I, $313 \mathrm{n}$. 8) onwards as a conversion of an Arian church to Catholic use in the sense of reconsecration. The Latin used, that Gregory I 'dedicavit to Saint Agatha the church of the Goths in the Subura', indicates appropriation of the church for the papal promotion of the cult of the martyr Agatha, similar to the takeover of the Pantheon for Saint Mary and the martyrs.

31 Propter adunationem ecclesiae et religionis and ibique occurrit multitudo male habentes et salvantur, LP I, Life 60, cc. 1 and 9, 290 and 293; trans. Davis, 52 and 53-4. 
Similarly Belisarius is eventually transformed from a protector of Rome into someone subsequently responsible for the deposition of Pope Silverius, and then into a benefactor of Saint Peter and founder of a xenedochium near the Via Lata. A later medieval inscription recording his gift survives inserted into the wall of the current church of Santa Maria di Trevi in Rome. ${ }^{32}$ Vigilius (53755) himself, elevated by Belisarius once Silverius had been removed so summarily, and subsequently driven from Rome by an outraged populace, is by the end of the Life rendered a champion of papal authority and orthodoxy; the clergy request Narses to petition the emperor for Vigilius' return from his exile in Constantinople. ${ }^{33}$

With the Life of Pelagius I (556-61) there is another transformation of character. Pelagius is at first another political appointment and consequently presented as deeply unpopular. The Liber pontificalis claims that no bishop was prepared to ordain him; ${ }^{34}$ John, bishop of Perugia, Bonus, bishop of Ferentino, and a priest called Andrew of Ostia are named as the only clerics who could be found who were willing to consecrate him (non esset episcopus qui eum ordinaret, inventi sunt duo episcopi). ${ }^{35}$ The claim that the papal consecration was performed not by the usual three bishops required by canonical tradition but only by two prelates retrieved from more distant sees and a mere priest may also be a subtle way of undermining Pelagius' legitimacy to add to the allegation of lack of favour. It is then Narses the Byzantine military leader who is represented as helping Pelagius to rehabilitate himself by means of a liturgical celebration. ${ }^{36}$ Yet the contemporary epitaph of Pelagius I printed by Duchesne extols Pelagius's virtues and his earning of blessedness in heaven. ${ }^{37}$ This would suggest that the pope's deployment of the liturgy in self-exoneration succeeded at least as far as the public display and commemoration of Pelagius' reputation for posterity was concerned, even if the Liber pontificalis authors later chose to let the murkier elements of his career stand, as well as the apparent contrast between the Romans' wishes and those of the Byzantine military command.

The scheme above highlights the selective choice of events reported in the remaining Lives of this section. This set of Lives seems to be an attempt to provide a brief historical update in annal style, rather cursorily fitted into the basic formulaic structure of the serial biography so that the framework of the historical narrative is papal. Thus the Life of John III (561-74) mostly concerns Narses, and the further passage of events with the arrival of the Lombards is placed in the time of Benedict I (575-9). Nevertheless, particular points are

\footnotetext{
32 LP I, Life 60, cc. 7 and 8, 292-3; LP I, Life 61, c. 2, 296 and 300 n. 7.

33 LP I, Life 61, 296-9.

34 The Bishop of Ostia is specified as consecrating Mark, LP I, Life 35, c. 2, 202; the earliest reference to the bishops of Ostia, Portus and Albano normally having this responsibility is in the Life of Leo II, LP I, Life 82, c. 6, 360 and 362 n. 23.

35 LP I, Life 62, c. 1, 303.

36 See R. McKitterick, 'Liturgy and history in the early Middle Ages', in M. Fassler, K. Bugyis and A. Kraebel (eds), Music, Liturgy, and the Shaping of History (800-1500) (York, 2016).

37 LP I, 304 n. 7.
} 
made about the pope's maintenance of orthodoxy and the place of Saint Peter's see as head of all the churches, the regulation of papal election, papal care of the clergy and papal endowment of churches.

A particularly striking aspect of this batch of Lives is the recurrent ambivalence of the presentation of papal relations with Byzantium in the aftermath of the Gothic Wars, both with the emperor himself and with the Byzantine military and civil officials in Italy, many of whom were recruited from the local population. ${ }^{38}$ Indications of the authors' critical attitude to Byzantine intervention in the process of papal election are found, for example, in the report of Narses being involved in ensuring Pelagius I's recognition. As mentioned above, it is Narses the Byzantine general who is credited with the plan to use the liturgy and a procession to Saint Peter's as a way to exonerate Pelagius from the accusation of being implicated in the death of Pope Vigilius. But when under Pelagius I's successor the Romans turn against Narses and send a petition against Narses to the emperor, it is the pope, John III, who takes the retired general under his wing despite the Romans' attitude, and it is in Rome that Narses died. ${ }^{39}$ The pope is here in control, even though it is Narses who is held responsible for inviting the Lombards into Italy. For Pelagius II (579-90), moreover, the author of Life 65 simply notes that the Lombard siege of Rome prevented the emperor's mandate being received before Pelagius was ordained.

The 'Byzantine Reconquest' thus appears by no means to have been a largescale foreign occupation, and there is little to indicate an influx of Byzantine officials beyond the exarchate of Ravenna itself, or the jurisdiction of Byzantine officials beyond the military sphere. ${ }^{40}$ This section of the Liber pontificalis raises a number of questions about the degree, or nature, of Byzantine 'control' in this period. Two letters from Pelagius I to Sindula magister militum suggest moreover that Sindula had to cede military cases involving the assessment of liability for damage and rights of inheritance, but that, significantly, he applied to the pope for advice. Such interventions may relate to the complications of acting on the provisions concerning property in the 'pragmatic sanction' of $554 .{ }^{41}$

38 See C. Diehl, Études sur l'administration byzantine de l'Exarchat de Ravenne (Paris, 1888) and T.S. Brown, Gentlemen and Officers: Imperial Administration and Aristocratic Power in Byzantine Italy AD 554-800 (Rome, 1984).

39 LP I, Life 63, c. 2, 305.

40 T.S. Brown, 'Settlement and military policy in Byzantine Italy', in H. Blake, T. Potter and D. Whitehouse (eds), Papers in Italian Archaeology I: The Lancaster Seminar. Recent Research in Prehistoric, Classical and Medieval Archaeology, 2 vols (BAR Supplementary Series 41) (Oxford, 1978), II, 323-38.

41 P. Jaffé, Regesta pontificum Romanorum ab condita ecclesia ad annum post Christum natum MCXCVIII, 2 vols (Leipzig, 1888), I, 130, 135, 990 and 1031; compare L.R. Loomis, Book of the Popes (New York, 1916), 163-4 n. 3 and the Constitutio pragmatica c. 12, ed. R. Schoell and W. Kroll, Corpus Iuris Civilis III: Novellae (Berlin, 1928), 799-802 at p. 800. See also M.S. Bjornlie, Politics and Tradition between Rome, Ravenna and Constantinople: A Study of Cassiodorus and the Variae 527-554 (Cambridge, 2013), 14. The manuscript tradition and knowledge of the Constitutio pragmatica in Rome in the decades after 554 merits further investigation. 
It should be remembered that Boniface IV's immediate predecessor Boniface III (February-November 607) had countered Constantinople's claim to ecclesiastical primacy by getting Emperor Phocas to concede the claim first made by Pope Leo I that Saint Peter's apostolic see, namely Rome, should be head of all the churches. It was also during his pontificate that the statue of Emperor Phocas was erected on a recycled plinth and column in the Forum by the exarch Smaragdus, though this is not recorded in the Liber pontificalis. Whether the two events are connected is a matter of speculation only. The inscription on the plinth, referring simply to Smaragdus' indebtedness to the emperor, would not suggest that the pope was involved unless, despite the usual assumption that the public space of Rome was under the exarch of Ravenna's jurisdiction, the significant location in the Forum itself had been a matter of negotiation. ${ }^{42}$ The Lives of Gregory I (590-604) and of Sabinian (604-6) before that are mostly concerned with papal activities as pastor and benefactor. The entry for Gregory I, however, slips in a brief note about the military governor of Ravenna visiting Rome and on his return to Ravenna recapturing cities held by the Lombards. Sabinian took advantage of the peace made with the Lombards soon thereafter to order the church's granaries opened up to relieve Rome's famine. The fact that Sabinian sold the grain rather than giving it away may be the reason for the odd route taken by his funeral cortège, that is, to avoid angry demonstrations. ${ }^{43}$ Further tensions between those in Rome and the exarch in Ravenna occupy much of the Lives of Boniface IV (608-15) and Deusdedit (615-18), but nothing in these Lives indicates that there was a Byzantine or Ravennate official presence in Rome itself. ${ }^{44}$ The patrician Eleutherius is based in Ravenna and represented as restoring peace and defeating the rebel John of Compsa in Naples. Boniface V (619-25) is even described as from Naples and the son of John. It would be tempting to think the Liber pontificalis author is telling us that Boniface was the son of the very John who had rebelled against the rulers of Ravenna. John is a common enough name but in this Life it is then Eleutherius who 'assumed the kingship' (whatever that may mean), was killed as a rebel and his head was taken to Constantinople. ${ }^{45}$

42 R. Coates-Stephens, 'Byzantine building patronage in post-reconquest Rome', in M. Ghilardi, C.J. Goddard and P. Porena (eds), Les cités d'Italie tardo-antique (IVe-Vie siècle) (Collection de l'École Française de Rome 369) (Rome, 2006), 149-66. Of interest for his nineteenth-century visitor's description is F.M. Nichols, 'A revised history of the Column of Phocas in the Roman Forum', Archaeologia 52 (1890), 1-12.

43 This was Duchesne's suggestion: LP I, Life 67, 315 and n. 4.

44 The ambiguity of the evidence is clear from the study by B. Bavant, 'Le duché byzantin de Rome. Origine, durée et extension géographique', Mélanges de l'École Française de Rome. Moyen Âge, Temps Modernes 91.1 (1979), 41-88; see also Gantner, Freunde Roms (above, n. 1), 64 n. 185, and the earlier study, not mentioned by either: P. Llewellyn, Rome in the Dark Ages (London, 1971), 140.

45 There is no other evidence to support this suggestion. On the popularity of the name John see P. Llewellyn, 'The names of the Roman clergy', Rivista di Storia dell Chiesa 35 (1981), 355-70. 
A further problematic reference is that to Boniface IV's famous request to Emperor Phocas to convert the Pantheon (templum qui appellatur Pantheum) to Christian use. ${ }^{46}$ Could this be regarded as a mere gesture towards Byzantine claims? Could Phocas actually have prevented it? What precisely was the legal status of the Pantheon in terms of ownership? Are the authors of the Liber pontificalis really using this device to indicate that in this pope we have another pontiff with sympathies towards at least Emperor Phocas that were not necessarily shared by his administration? Or is consecration of the Pantheon a simple record of the appropriation of a major city landmark for ecclesiastical use? Now dated 13 May 613 (rather than 609), this was also the conversion of a public building, by this time a secular building possibly used for judicial purposes, into a sacred one that assumed an important role in the developing stational liturgy of the popes. ${ }^{47}$ The Alleluia and verse in the liturgy devised for this special dedication, as well as the texts from Chronicles drawn on for the Offertory, invoke the temple of Solomon (Adorabo ad templum sanctum tuum: et confitebor nomini tuo from Psalm 137:2), and the building and dedication of the temple in Chronicles. It is these liturgical references that are surely implied in the use of the word templum by the Liber pontificalis authors in addition to its older historical function. Pagan temples had been closed by Emperor Theodosius over 200 years earlier (Codex Theodosianus 14.3.10), but even before that images of emperors had replaced those of gods in the niches inside the building, ${ }^{48}$ and law was publicly announced there in 368 or $370 .{ }^{49}$ Despite his own work on the Jewish temple, Bede appears to have reacted to the use of the word templum in the Liber pontificalis in his own peculiar context and assumed that the reference in the Liber pontificalis was to the conversion of a pagan temple, necessitating the elimination of 'abominations' (spurcitia). ${ }^{50}$ But the papal conversion of this building, its transformation into a house of God and of prayer, its dedication to Mary and all the martyrs, and the liturgy that celebrates the building as a gateway

$46 \quad$ LP I, Life 69, c. 2, 317.

47 The reality of this exchange needs fuller investigation than is feasible here. See further below, pp. 262-3; S. de Blaauw, 'Das Pantheon als christlicher Tempel', in H. Brandenburg, M. JordanRuwe and U. Real (eds), Bild und Formensprache der spätantiken Kunst: Hugo Brandenburg zum 65. Geburtstag (Boreas 17) (Münster, 1994), 13-26; S.K. Rankin, 'Terribilis est locus iste: the Pantheon in 609', in M. Carruthers (ed.), Rhetoric beyond Words: Delight and Persuasion in the Arts of the Middle Ages (Cambridge, 2011), 281-310; T.A. Marder and M. Wilson Jones, 'Introduction', in T.A. Marder and M. Wilson Jones (eds), The Pantheon from Antiquity to the Present (Cambridge, 2015), 1-48. On the stational liturgy see J.F. Baldovin, The Urban Character of Christian Worship (Orientalia Christiana Analecta 228) (Rome, 1987), 106-18.

48 Ammianus Marcellinus, Rerum gestarum libri XVI.10.13-14, ed. J.C. Rolfe (Cambridge [MA], 1956), 249-50.

49 See E. Thunø, 'The Pantheon in the Middle Ages', in Marder and Wilson Jones (eds), The Pantheon (above, n. 46), 231-54 at pp. 231-2; R. Coates-Stephen, 'Re-use of ancient statuary', in F.A. Bauer and C. Witschel (eds), Statuen in der Spätantike (Wiesbaden, 2007), 171-88.

50 Bede, Historia ecclesiastica gentis Anglorum II.4, ed. B. Colgrave and R.A.B. Mynors, Bede, The Ecclesiastical History of the English People (Oxford, 1969), 148-9. 
to heaven, have nothing to do with a far-off memory of paganism. ${ }^{51}$ Instead, it is a wonderful symbol of the incorporation of a supremely Roman public building into the public liturgy of the pope within the city. Similarly, the Roman Curia in the forum was turned into the church of Sant'Adriano under Pope Honorius (62538 ), with no indication of imperial approval or the lack thereof. ${ }^{52}$ This again underlines the ability of the pope, at least as represented in the Liber pontificalis, to assert his authority over buildings once regarded as centres of Roman governmental and judicial affairs, and to transform their status and function.

Further, the reference in Boniface V's Life to the validity of wills secundum iussionem principis may well be a reference to the Codex of Justinian, attested in Italy in sixth-century manuscripts, or conceivably the Novellae, which were available in Italy in their Latin version. The 'Pragmatic constitution of 554' made many references to the validity of sales, gifts and exchanges but did not specify wills. ${ }^{53}$ Recent work has suggested that the laws of Justinian, especially the Novellae, were regarded as laws for use more generally. Even the Lombard kings referred to the Novellae. Such references do not necessarily establish that an area was still under Byzantine control, or where legislative and judicial authority was located, but simply that Roman law, including the new legislation of Justinian, remained part of a body of legal principles to which reference could be made in Italy. ${ }^{54}$

This section of the Liber pontificalis, therefore, appears to set the tone of, if not actually define, a set of attitudes about the position of the bishop of Rome. The Liber pontificalis engineers the formation of perceptions of Byzantium and the papacy. The text makes better sense indeed if it is seen not as a passive record but as active persuasion and a pointed presentation of select incidents, so that the strangely imbalanced and laconic text becomes significant in its very selectiveness.

\section{THE SECOND AND THIRD CONTINUATIONS OF THE LIBER PONTIFICALIS}

Let us now look at two further groups of Lives or continuations, which I set out in a schematic summary similar to that provided for Lives 60-71 (with the same acronyms used for the abbreviated formulaic elements):

51 Compare Rankin, 'Terribilis est locus iste' (above, n. 46), 83, who follows Bede in maintaining that this was the conversion of a pagan temple. See also C. O'Brien, Bede's Temple: An Image and its Interpretation (Oxford, 2015).

52 LP I, Life 72, c. 6, 324 and 326-7 n. 18. See G. Bordi, 'Committenza laica nella chiesa di Sant'Adriano al foro romano nell'alto medioevo', in A.C. Quintavalle (ed.), Medioevo: I committenti (I Convegni di Parma 13) (Milan, 2011), 421-32.

53 C. Radding and A. Ciaralli, Corpus Iuris Civilis in the Middle Ages: Manuscripts and Transmission from the Sixth Century to the Juristic Revival (Leiden, 2007).

54 I owe these points to P. Sarris, "Whose law is it anyway? The "Novels" of the Emperor Justinian and legal culture in the early Middle Ages', a paper delivered to the Cambridge University Medieval History Research Seminar, 15 October 2015. See also McKitterick, 'The damnatio memoriae of Pope Constantine II' (above, n. 16). 
LP IIB (second and third continuations): Lives 72-81 Honorius to Agatho (AD 625-81)

Life 72 Honorius NNNL; restoration of buildings in Rome; liturgy; monasteries founded; DBOV

Life 73 Severinus NNNL; plundering of the Lateran episcopium by Maurice the cartularius; OBV

Life 74 John IV NNNL; redemption of Dalmatian captives; buildings for Istrian martyrs; DBOV

Life 75 Theodore NNNL; virtues; iniquities of Maurice and Isaac, the Byzantine exarchate officials; arrival of Patriarch Pyrrhrus of Constantinople; martyrs and new churches and oratories; Patriarch Paul accused of unorthodoxy and deposed; DBOV

Life 76 Martin NNL; Paul persecutes papal officials in Constantinople; Lateran Synod; Olympias with army to Rome; Martin exiled; DBO

Life 77 Eugene NNNL; virtues; patriarch sends a letter and people and clergy in Santa Maria Maggiore make Eugene reject it; DBOV

Life 78 Vitalian NNNL; synodic letter to emperors; pope maintains discipline; Emperor Constans II visits Rome; strips roof of Santa Maria ad Martyres; DBOV

Life 79 Adeodatus NNNL; virtues; Mezesias seizes kingship; Saracens in Sicily; Adeodatus restores Saint Peter on Via Portuensis; founds Saint Erasmus monastery; portents; litanies to placate God; DBOV

Life 80 Donus NNNL; repairs to churches; Syrian monks settled in Rome; Roman monks replace Syrian Nestorian monks in Boethian monastery; Ravenna restored to apostolic see; portent; DBOV

Life 81 Agatho NNNL; virtues; Theodore of Ravenna in Rome; invitation to Agatho to come to Constantinople to achieve unity; Council in Trullo; DBOV

LP IIC (second and third continuations): Lives 82-90 Leo II to Constantine I (AD 682-715) Life 82 Leo II NNNL; praise of his learning; receives and translates acts of Sixth Council; supplements Agatho's Life; imperial mandate restores Ravenna; builds church dedicated to Paul; lunar eclipse; OBV and belated note of who consecrated him bishop

Life 83 Benedict II NNNL; praise of his learning and musical skill; restoration of churches; receives mandates from emperor about election and locks of hair of emperor's sons; portents; bequest to clergy; DBOV

Life 84 John V NNNL; virtues; election; present at Trullo; Justinian II's succession and l'affaire Citonatus; illness (cf. Conon); bequest; DBOV

Life 85 Conon NNNL; disputed election; messages to Exarch Theodore; imperial mandate to uphold Trullo and abolition of imperial taxes in Bruttium and Lucania; administration in Sicily; Exarch John of Ravenna bribed to interfere in papal election; bequest; illness (cf. John V); DBOV

Life 86 Sergius NNNL; praise of his virtues and musical skill; disputed election; exarch's interference; Acts sent to Rome to be signed; Sergius refuses; Byzantine attempt to kidnap Sergius led by the spatharius Zacharias; discovery of Cross fragment in Saint Peter's; other churches restored and embellished; Leo I translated to new tomb in Saint Peter's basilica; Sergius inaugurates Agnus dei in the mass and new Marian litanies; Aquileia restored to communion with Rome; archbishops for Britain, Frisians and Ravenna; BOV

Life 87 John VI NNNL; Patriarch Theophylact visits Rome; Gisulf ravages Campania; churches of Saint Andrew, Mark and Paul embellished; BOV

Life 88 John VII (first portion) NNNL; learning and eloquence; many churches embellished including Santa Maria Antiqua; D; (second portion) Justinian II sends the acta of the Quinisext Council, John refuses to emend them; DO

Life 89 Sisinnius NNNL (20 days); gout; restoration of walls; DOV

Life 90 Constantine NNNL; virtues; famine/plenty in Rome; Felix of Ravenna: those who disobeyed the apostolic see died a bitter death; Constantine visits Constantinople and Emperor Justinian prostrates himself before the pontiff; heretic emperor Philippicus and 
rejection of Peter as dux of Rome; Botarea in Saint Peter's; Anglo-Saxon kings visit Rome; Benedict of Milan reconciled; dukedom of Rome; Emperor Anastasius succeeds; triumph of orthodoxy and imperial mandate acknowledging sixth council presented to pontiff; OV

As we have seen, the events in section IIA formed the backdrop to the succession of Honorius, whose Life is entirely taken up with his building work. It is usually to Honorius' pontificate (625-38), furthermore, that this updating of the Liber pontificalis and the composition of lives $60 / 61-72$ is attributed. It is difficult to pin the stages of composition down more precisely, but some suggestions can be made here by focusing on the principal message conveyed by the text. This appraisal has to acknowledge that the few papal letters extant from this period (no papal letters exist for the period 604-25) make it possible to discern only occasionally a little of what the Liber pontificalis was either suppressing or understating. ${ }^{55}$ My purpose here however is to study the Liber pontificalis' representation of the events and issues.

First of all, it would appear that the composition of the Liber pontificalis was resumed because it again had a specific role to play, both in propagating a representation of the papal challenge to Byzantium and the patriarch of Constantinople in doctrinal matters, and in reporting the sequence of events as an historical record. In other words, the Liber pontificalis was refocused in relation to monothelitism. ${ }^{56}$ No mention at all of doctrine or the popes' communications with Constantinople is made in the Lives of Honorius, Severinus and John IV. Only the beginnings of the aggressive military interventions on the part of the exarch in Ravenna are signalled in the Life of Severinus, with a dramatic account of the disgraceful plundering of the episcopium of the Lateran by Maurice the cartularius.

The Life of Honorius is silent about his apparent intervention in the doctrinal discussions in Byzantium and statement of one will in Christ, for which he was condemned at the Council of Constantinople in 681. Catherine Cubitt has suggested that the thrust of Honorius' first letter to Patriarch Sergius was actually to agree with Sergius' rejection of the notion of one or two operations in Christ and to defend Chalcedon, even if Honorius did make the statement about one will. ${ }^{57}$ Honorius' second letter to Sergius reiterates the Chalcedonian position. An exchange of information and documents, including consultation of

55 P. Conte, Chiesa e primato nelle lettere dei papi del secolo VII (Rome, 1971). See also P. Booth, Crisis of Empire: Doctrine and Dissent at the End of Late Antiquity (Berkeley, 2014), 259-77.

56 See M. Jankowiak, 'The invention of Dyothelitism', Studia Patristica 63 (2013), 335-42.

57 See C. Cubitt, 'The Roman perspective,' in Price, Booth and Cubitt, The Acts of the Lateran Synod of 649 (above, n. 5), 40-58 at p. 46. See also A. Thanner, Papst Honorius I. (625-638) (Studien zur Theologie und Geschichte 4) (St Ottilien, 1989); P. Allen and B. Neil, Maximus the Confessor and his Companions: Documents from Exile (Oxford, 2002), 14-20; and P. Allen, Sophronius of Jerusalem and Seventh-Century Heresy: The Synodical Letter and Other Documents (Oxford, 2009), 194-208. The older discussion by J. Chapman, The Condemnation of Pope Honorius (London, 1907), is still of some value, though directed at early twentiethcentury discussions about papal infallibility. 
the papal letter Register, within the papal offices in the Lateran, may have meant that the authors of the Liber pontificalis had also read Honorius' letters. The Life of Leo II (682-3) records the receipt of the canons of the Sixth Council (of Trullo) in Greek and the fact that Leo had translated them into Latin. These included the condemnation of Honorius but, again, no further comment is offered in the Liber pontificalis; the text simply insists on the orthodox position of Christ's two wills. ${ }^{58}$ This omission of any role for Pope Honorius in the initial statements of the monothelite view, and its presentation as an entirely Byzantine proposition, made it possible to portray the succeeding popes as unfaltering champions of orthodoxy.

Thus the Life of Theodore (642-9) recounts how Pyrrhus, former patriarch of Constantinople, came from Africa to Rome and professed his orthodoxy in alignment to Rome. Despite being honoured by the pope 'as the sacerdos of the imperial city' (honorans eum et sacerdotem regiae civitatis), he subsequently recanted and the pope was summoned to a synod in Saint Peter's in order to condemn and depose Pyrrhus, who then 'returned to the districts of the east'. ${ }^{59}$ The pope also wrote to Paul, the incumbent patriarch in Constantinople, reproving him for his unorthodoxy in writing and orally through his apocrisiarii. Paul remained obdurate and the pope deposed him as well. Paul's retaliation is described in the Life of Martin I (649-55). The patriarch induced the emperor to issue a 'Typus which would destroy catholic dogma' (ut et clementissimo principi suadere typum exponere qui catholicam dogmam distrueret) and to overthrow the altar of the holy see in a special oratory in the house of Placidia. This prevented the papal legates from celebrating orthodox mass. The apocrisiarii, other orthodox men and sacerdotes were beaten, imprisoned or exiled. Pope Martin responded to pleas to the pope to eradicate this threat to catholic unity by convening a synod in the Lateran attended by 105 bishops, at which Cyrus of Alexandria, Sergius, Pyrrhus and Paul, all successively patriarchs of Constantinople, were condemned. ${ }^{60}$ In consequence imperial wrath fell on Martin; the newly appointed exarch of Ravenna, Theodore Calliopas, and the chamberlain Theodore Pellurius abducted Pope Martin and brought him to Constantinople. Martin remained steadfast and was exiled to Cherson, where he died. ${ }^{61}$

The Liber Pontificalis authors maintain the hostile resistance to the theological position adopted in Constantinople in the Life of Eugene I (654-7), with its description of the synodic letter sent 'following custom' (iuxta consuetudinem) from Patriarch Peter to Rome: 'it was completely unintelligible, failing to be explicit about the operations and wills in our Lord Jesus Christ' (omnino

\footnotetext{
$58 \quad$ LP I, Life 82, c. 2, 359.

59 LP I, Life 75, c. 3, 332; trans. Davis, 66.

60 LP I, Life 76, cc. 1-3, 336-7.

61 LP I, Life 76, c. 8, 338. See B. Neil, Seventh-Century Popes and Martyrs: The Political Hagiography of Anastasius Bibliothecarius (Studia Antiqua Australiensia 2) (Turnhout, 2006). See also Booth, Crisis of Empire (above, n. 54), 278-313.
} 
obscurissimam et ultra regula, non autem declarans operationes aut voluntates in domino nostro Iesu Christo). The people and clergy at mass in Santa Maria Maggiore made the pope promise to reject it. ${ }^{62}$ The next Life, of Vitalian (65772 ), then neatly denigrates the emperor himself. Constans II's visit to Rome is irretrievably marred by his plundering not only of the bronze tiles and statues from the church of Santa Maria ad Martyres in Rome, but also of the provinces and holy churches of Calabria, Sicily, Africa and Sardinia 'for years on end' (per annos plurimos). ${ }^{63}$ This portion of the narrative reaches its climax with the Life of Agatho (678-81), and his sending of a notably large group of legates to represent the pope to the Council in Constantinople, later called the Council of Trullo. ${ }^{64}$ Their formal and courteous reception and their presentation of the arguments in favour of orthodoxy on Agatho's behalf are described in detail. The presentation included close examination of 'all the books they knew to deal with the matter of faith at issue' (omnes libros quos scirent ad causam fidei pertinere). It was Saint Peter who on 14 February 'helped the light of truth appear' (auxiliante beato Petro apostolo ut veritatis lumen appareret), and in the next day's session the 'synodal letter of the holy pope Agatho' (synodica sanctissimi Agathonis papae) was read out, and to prove each point the statements of the Fathers were inserted; 125 of the western bishops had subscribed to this letter. ${ }^{65}$ Saint Peter and his successor the pope, therefore, are the triumphant champions of orthodoxy. A further enhancement of the 'grace of almighty God granted to the envoys of the apostolic see' (tanta gratia divina omnipotentis concessa est) was that John, bishop of Portus, celebrated a public mass in Latin in the church of Saint Sophia in Constantinople itself, at which emperor and patriarch were present. No reader of the Liber pontificalis could fail to register this public demonstration of the pope's theological and ecclesiastical standing.

The final group of Lives in the late seventh- and early eighth-century continuation serves to consolidate the leadership of the pope in doctrinal matters, as well as give hints of the further diminution of formal diplomatic connections. The popes, moreover, are linked with each other personally as well as with Pope Agatho in terms of their service and the person who ordained them, and in the various ways in which they receive acta from synods convened in Constantinople. A significant number of popes - Leo II, Benedict II, John V, Sergius - are praised for their learning and/or skill in singing, attributes rarely noted elsewhere by the Liber pontificalis authors. ${ }^{66}$

\footnotetext{
62 LP I, Life 77, c. 2, 341; trans. Davis, 69.

63 LP I, Life 78, c. 3, 343; trans. Davis, 70

64 LP I, Life 81, c. 3, 350.

65 LP I, Life 81, cc. 8, 9, 352; trans. Davis, 73, 74, 75.

66 On the emergence of chant as a major aspect of the liturgical ritual life of Rome in the seventh century see especially C. Page, The Christian West and its Singers: The First Thousand Years (New Haven, 2010), 243-61.
} 
Thus Pope Leo II (682-3), praised for his proficiency in Greek and Latin, as well as for his learning and skill in singing, is credited with translating the acta of the Sixth Oecumenical Council into Latin. Only in this reference is the name of Honorius included in the list of those condemned by the synod as supporters of the idea of 'one will and operation in Christ', followed by a reiteration that '[f]rom now on, two wills and operations must be spoken of in Christ our God'.67 The introductory section of John V's Life (685-6) stresses that, even though he was originally from Antioch, he had served the Roman church throughout his career. It inserts the information that John, while still a deacon, had been sent by Agatho to the Sixth Oecumenical Council in Constantinople, and it was he who brought back all the documents relating to the synod's proceedings as well as mandates abolishing many imperial taxes. ${ }^{68}$ The author of this Life also makes a point of mentioning that John was consecrated by the same three bishops who had consecrated his predecessor Leo II. The theme of imperial confirmation of the Sixth Oecumenical Council being sent to the pope is maintained in the Life of Conon (686-7). ${ }^{69}$

This accord was disrupted, however, during the pontificate of Sergius (687701). Sergius' orthodox credentials are first firmly established by the author of his Life. The pope was born in Sicily but his family was originally from Antioch, so this raises the possibility that the family had been orthodox refugees from Syria. Sergius was trained in Rome from the time of Pope Adeodatus (672-6). He rose through the ecclesiastical grades and was ordained priest by none other than Pope Leo II. Like Leo II, moreover, Sergius is praised for his skill as a singer, and for his learning. Sergius adamantly refused to approve or subscribe to the disciplinary decrees of the 'Quinisext Council' (also held, like the Sixth Council, in Trullo) convened by Emperor Justinian II. The emperor sent his spatharius Zacharias but the latter, due to the assistance rendered to Sergius by the soldiers of Ravenna and the Pentapolis, failed ignominiously to force Sergius, in an attempt reminiscent of the treatment of Pope Martin I, to go to Constantinople. The authors of the Life add the comment: 'by Christ's favour was God's church, with its prelate, preserved undisturbed' (sicque ecclesia dei inperturbata cum suo praesule Christo favente servata est). ${ }^{70}$ The rest of the Life further buttresses Sergius' position by relating the stories of his discovery of a fragment of the 'True Cross' and inauguration of the feast of the Exaltation of the Holy Cross, ${ }^{71}$ of his ceremonial translation of the body of an earlier champion of Chalcedonian orthodoxy, Pope Leo I, to

67 LP I, Life 82, c. 2, 359; trans. Davis, 76.

68 LP I, Life 84, c. 2, 366; on the taxes see below, p. 264.

69 LP I, Life 85, c. $3,368$.

70 LP I, Life 86, cc. 6-9, 372-3; trans. Davis, 82-3.

71 See E.Ó. Carragaín, 'Interactions between liturgy and politics in Old Saint Peter's, 670-741: John the Archcantor, Sergius I and Gregory III', in McKitterick, Osborne, Richardson and Story (eds) (above, n. 3), Old St Peter's, 177-89. 
an elaborate tomb, the introduction of the Agnus dei into the mass and the liturgical enhancement of the cult of Mary the Virgin. ${ }^{72}$

Having regained his throne, Justinian II tried again to get the pope to subscribe to the Quinisext decrees. This brings us back to the Life of John VII, with which I began this paper. In highlighting John VII's 'weakness' in simply sending the same acta which Sergius I had rejected back to Constantinople without either endorsing or emending them, the authors of the Liber pontificalis provided yet another episode in the doctrinal dispute with Constantinople. They thereby prepared the way for the triumphant conclusion of this section of the Liber pontificalis with the achievement of Pope Constantine I. Pope Constantine I with a substantial retinue sailed to Constantinople in 710 having been summoned by the emperor. ${ }^{73}$ Thereafter he is portrayed as clearly the superior presence. He was greeted by the co-emperor Tiberius in Constantinople and then had to travel to Nicomedia, where he met Emperor Justinian II. In a remarkable act of obeisance, the emperor prostrated himself and kissed the feet of the pontiff; the text then relates how 'they rushed together in mutual embrace' (in amplexu mutuo corruerunt). Constantine performed mass for the emperor; 'the prince communicated at his hands and craved the pontiff to pray for his sins' (et communicans princeps ab eius manibus proque suis delictis ut deprecaretur pontificem postulans). ${ }^{74}$ The Life ends with the report of the deposition of the heretic emperor Philippicus and the installation of Anastasius. The emperor then declared himself a supporter of the orthodox faith to the pope and once again there is an affirmation of the Sixth Oecumenical Council, echoing that of 'the whole population of Rome, in their burning enthusiasm for the faith, [who] erected in Saint Peter's the image which the Greeks call Botarea: it includes the six holy universal synods' (Huiusque rei causa zelo fidei accensus omnis coetus Romane urbis imaginem, quod Greci Botarea vocant, sex continentem sanctos ac universales synodos, in ecclesia beati Petri erecta est). ${ }^{75}$

The implications of the argument so far for the composition of the Liber pontificalis are as follows: the initial updating and reframing of the Liber pontificalis in what I have labelled the 'first continuation' included Honorius' pontificate and that of his successors Severinus and John IV. An extra dimension may have been added by what Peter Llewellyn has characterized as a reaction within the secular clergy in the seventh century to the monastic emphases of Pope Gregory I's incumbency. ${ }^{76}$ Certainly the Liber pontificalis'

\footnotetext{
72 LP I, Life 86, cc. 10, 14, 374-6.

73 LP I, Life 90, c. 3, 389.

74 LP I, Life 90, c. 6, 391; trans. Davis, 88 .

75 LP I, Life 90, c. 8, 391; trans. Davis, 93. It is doubtful that this can taken as an early indication of the issue of iconoclasm that was to become so prominent in the agenda of doctrinal discussion in the eighth century: but see M.T.G. Humphreys, Law, Power, and Imperial Ideology in the Iconoclast Era, c. 680-850 (Oxford, 2015) and L. Brubaker and J. Haldon, Byzantium in the Iconoclast Era, c. 680-850: A History (Cambridge, 2011).

76 P. Llewellyn, 'The Roman clergy in the seventh century', Journal of Ecclesiastical History 25 (1974), 363-80.
} 
account of the events leading up to the Lateran Synod of 649 affords little room for monks, let alone the profound influence exerted by Palestinian monks that modern commentators have discerned. ${ }^{77}$ Given the consistent emphasis that emerges in the text, an updated and extended version of the Liber pontificalis seems more likely to have been undertaken in the context of the pontificates of Theodore and Martin I (642-9). At that stage the text may have been envisaged as part of the dossier of material prepared for the Lateran Synod of 649. The determined upholding of orthodoxy against the machinations of Byzantine patriarchs and emperors, established by the authors for the Lives of Theodore and Martin, is then sustained throughout the second and third continuations to encompass first of all the Lives up to Pope Agatho and the Council of Trullo, and thereafter up to the ceremonial visit of Pope Constantine I to Constantinople, the abasement of the emperor before the pope and the triumph of orthodoxy.

\section{THE LIBER PONTIFICALIS' REPRESENTATION OF THE LIMITS OF BYZANTINE INTERVENTION IN ROME}

Preoccupied with the doctrinal differences between the Byzantine emperors and patriarchs in Constantinople and the bishop of Rome, the Liber pontificalis also yields some meagre indications of a particular perception of the nature of the relationship between the emperor and the pope and the degree of political control exercised by the emperor or his official representatives in Italy. ${ }^{78}$ This representation of the bishop of Rome's diplomatic position in relation to Byzantium needs to be read within the context of the markedly firm stand claimed by the narrative's authors for the bishop of Rome in opposition to the theological position of the patriarch and emperor.

As mentioned above, permission is implied as being sought and granted concerning particular buildings in Rome, in addition to the consecration of the Pantheon acknowledged with gifts from Emperor Phocas. ${ }^{79}$ Pope Honorius had removed bronze tiles 'from the temple called that of Rome' (de templo qui appellatur Romae) 'with the assent of the pious Emperor Heraclius' (ex concessu piissimi Heraclii imperatoris) in order to reroof Saint Peter's. ${ }^{80}$ These references have been assumed to attest to Byzantine and imperial control in

77 P. Booth, 'The Palestinian perspective', in Price, Booth and Cubitt, The Acts of the Lateran Synod (above, n. 5), 27-40 and P. Allen and B. Neil (eds), The Oxford Handbook of Maximus the Confessor (Oxford, 2015).

78 I here modify existing interpretations of this evidence, most clearly elucidated by P. Llewellyn, 'The popes and the constitution in the eighth century', English Historical Review 101 (1986), 42-60, but wish nevertheless to acknowledge my indebtedness to Peter Llewellyn's path-breaking work on the politics of early medieval Rome.

79 LP I, Life 69, c. 2, 317.

80 LP I, Life 72, c. 2, 323; trans. Davis, 62. 
Rome, but such permissions raise more questions than can be addressed in the compass of this paper. Could the inclusion of this event have been a narrative device to emphasize Honorius' particular relationship with the emperor? Or does it simply reflect an underlying uncertainty about legal ownership? One possible reading is that the Liber pontificalis is representing the pope as resorting to an outside 'authority' that no one would feel able to question in order to justify his actions within the city. The later stripping of the bronze tiles of the Pantheon/Santa Maria ad Martyres by Emperor Constans may well come without comment after an elaborate description of the gifts he had made to Saint Peter's and Santa Maria Maggiore, but it is followed by direct criticism of his removal of sacred vessels from churches in Sicily. Maurice the cartularius' attack on the Lateran episcopium was represented as illicit plunder. ${ }^{81}$

The occasional references to the pope's election being reported to the emperor have been read in the past as an indication of the exercise of Byzantine authority in Rome. Yet the notices are often contradictory, and some of the authors responsible for the Liber pontificalis record nothing in this respect. Many are also problematic in that they appear to be only in the probably late seventhcentury Frankish recension of the Liber pontificalis known as the Cononian recension. ${ }^{82}$ Thus as early as the Life of Pelagius II (579-90), the Liber pontificalis reports that Pelagius, described as Roman and the son of (the Goth?) Unigild, was ordained without the emperor's leave (ordinatur absque iussione principis) because of the Lombard siege of Rome. ${ }^{83}$ But the slight suggestion that lack of a mandate might undermine Pelagius' position is apparently countered by the references to the pope's munificence to two of the greatest martyrs' shrines in Rome, those of Saint Peter himself, and also Saint Lawrence, his virtue in looking after the poor, his foundation of a monastery and his burial in Saint Peter's basilica. It needs to be noted that the Liber pontificalis claims in the Life of Eugene (654-7) that he too, when the Patriarch of Constantinople was ordained, customarily reported his ordination to the pope. ${ }^{84}$ The next allusion to a papal report of his ordination is not added until the reign of Vitalian (657-72) sixty years later, where the pope is reported as sending legates with 'the usual synodic letter to the pious emperors in the imperial city, informing him of his ordination' (Hic direxit responsales suos cum synodicam iuxta consuetudinem in regiam urbem ... significans de ordinatione sua), but with no reference to permission being either required or granted. ${ }^{85}$ This is an announcement of a fait accompli. Here the report

\footnotetext{
81 LP I, Lives 73, 75 and 78, 328-9, 331-2, 343-4.

82 On the Cononian recension and Frankish intervention in its preservation see R. McKitterick, 'Perceptions of Rome and the papacy in late Merovingian Francia: the Cononian recension', in S. Esders, Y. Fox, Y. Hen and L. Sarty (eds), East and West in the Early Middle Ages: The Merovingian Kingdoms in Mediterranean Perspective (Cambridge, forthcoming).

83 LP I, Life 65, c. 1, 309.

84 LP I, Life 77, c. $2,341$.

85 LP I, Life 78, c. 1, 385; trans. Davis, 69. Mommsen, Liber pontificalis (above, n. 20), 187 notes this too as a reading in the $\mathrm{K}$ text (=Cononian recension).
} 
resembles a diplomatic exchange. This impression is strengthened by the succeeding observation that when Vitalian's legates had secured the renewal of the church's privileges they returned home and the emperor sent a gift of a gold gospel book. What these privilegia ecclesiae may have comprised is not explained. This account is immediately followed by the visit to Rome of Emperor Constans II, who stayed for twelve days. He was given a ceremonial welcome, attended mass in Saint Peter's and visited the pope at the Lateran 'in the basilica of Vigilius'. The authors of the Liber pontificalis then firmly blight the memory and effect of the emperor's visit by reporting Constans' stripping of the bronze tiles from the roof of the Pantheon/Santa Maria ad Martyres, along with 'various other things he had dismantled' (alia diversa quas deposuerat direxit). ${ }^{86}$ In Pope Agatho's Life, however, the papal legate John is described as receiving, on request, abolition of a fee paid by the pope on his ordination, but the requirement still remained that the pope should not be ordained until after his election had been reported to the emperor and accepted. ${ }^{87}$ Even if this is to be regarded as a new attempt to assert control on the emperor's part rather than the continuation of an established practice, the requirement was abandoned only three years later. The Life of Benedict II (684-5) reports that Emperor Constantine IV conceded that the pope could be ordained immediately on election. ${ }^{88}$ The Liber pontificalis claims that, when Pope Constantine I visited Constantinople, the emperor 'renewed all the church's privileges' (omnia privilegia ecclesiae renovavit). Again, there are no clues as to what these might have comprised, or whether it was simply a grand gesture to be interpreted more as an imperial gift of devotion to Saint Peter than implying any jurisdictional prerogatives. ${ }^{89}$

That the pope was the one who negotiated the reduction or withdrawal of tax liabilities is also suggested by the Liber pontificalis. Thus Conon secured the abolition of the annonocapita in Bruttium and Lucania and the release of all dependants of the patrimony and of Sicily. ${ }^{90}$ Resentment of imperial taxation, moreover, added to what is presented as mounting resentment of the exarch of Ravenna's attempt to intervene with his army in Roman affairs. Indeed, the exarch of Ravenna's efforts on behalf of the emperor to use military force to carry out the emperor's orders are consistently reported as external and unjustifiable interference. ${ }^{91}$ Life 73 of Severinus (May-August 640) reports that the pope was ordained only after the plundering of the Lateran by Isaac the

86 LP I, Life 78, c. 3, 343; trans. Davis, 70. The Latin word is neutral but the outcome justifies Davis' choice of word in his translation of deposuerat.

87 LP I, Life 81, c. 2, 354-5.

88 LP I, Life 81, c. $2,354-5$ and 358 n. 34; compare LP I, Life 83, c. 3, 363.

89 LP I, Life 90, c. 6, 391; trans. Davis, 89. Whether this is indeed a remnant of real authority needs further investigation.

90 LP I, Life 85, c. $3,369$.

91 LP I, Lives 73, 75 and 76: Severinus (May-August, 640), Theodore (742-749) and Martin 749-753/755), 328-9, 331-3, 336-8. 
exarch of Ravenna and the sending of a portion to Emperor Heraclius. The see had been vacant for 19 months and 22 days after the death of Honorius (12 October 638)..$^{92}$ The plundering of the wealth appears to have been an opportunity seized by Maurice the cartularius 'driven by malice against God's church' (dolo ductus adversus ecclesiasm dei), who allegedly incited the 'Roman army' to occupy the vestry and episcopium of the Lateran. ${ }^{93}$ Isaac himself then arrived, was there for eight days and seized everything, sending a portion to Heraclius in Constantinople. ${ }^{94}$

If the exarch were really ruling Rome this would be an extraordinary thing to do. The Liber pontificalis in any case actually presents it as a period when Rome was unable to summon sufficient forces to prevent Isaac's action immediately. If Isaac and Maurice had really had an officially protective function in relation to Rome, then they certainly abused it. The emperor himself is implicated in what the Liber pontificalis authors represent as rapaciousness by receiving the portion of the stolen goods. Earlier in the Life these goods had been described as bequeathed by various Christian emperors, patricians and consuls 'for the redemption of their souls, for distribution of alms to the poor at particular times and for the redemption of captives' (pro redemptione animarum suarum beato Petro apostulo dereliquerunt, ut pauperibus ingulis temporibus pro alimonia erogarentur, seu propter redemptionem captivorum).95 This Life therefore makes it absolutely clear that exarch and emperor are rapacious enemies of Rome and only determined to exploit it.

In the Liber pontificalis, therefore, the pope' s benefactions and virtues are immediately extolled after this report of the vice of the exarch and Maurice. The material spoliation of Rome thus echoes the spiritual impoverishment of the emperor and patriarch of Constantinople already displayed in the obstacles they presented to the maintenance of orthodoxy. The disputed elections of both Conon in 686 and Sergius I in 687 offered further opportunities for the exarch of Ravenna to attempt to intervene in Roman affairs, prompted by candidates and their factions in Rome seeking support from Ravenna. The overall impression the Liber pontificalis creates is that this interference was both unwonted and unwanted. The authors are at pains to stress how universal Sergius' support was, as the judges, the army, the majority of clergy and a crowd of citizens settled on Sergius and brought him to the Lateran episcopium. ${ }^{96}$ Similarly, the interference of the exarch of Ravenna in the

\footnotetext{
92 Byzantium's territorial losses in the 630s are particularly pertinent here: see J. Haldon, Byzantium in the Seventh Century: The Transformation of a Culture, revised edition (Cambridge, 1997), A. Louth, 'Byzantium transforming', in J. Shepard (ed.), The Cambridge History of the Byzantine Empire, c. 500-1492 (Cambridge, 2008), 221-48 and P. Sarris, Empires of Faith: The Fall of Rome to the Rise of Islam, 500-700 (Oxford, 2011), 245-74.

93 LP I, Life 73, c. 1, 328; trans. Davis, 63.

94 LP I, Life 73, c. 4, 328.

95 LP I, Life 73, c. 3, 328; trans. Davis, 64

96 LP I, Lives 85 and $86,368,371-2$.
} 
appointment of the $d u x$ of Rome appears to have been rejected, though the Liber pontificalis yields little precise information about this office. ${ }^{97}$

The ecclesiastical status of Ravenna's archbishop in relation to Rome is another factor to be considered: it is unclear for most of the seventh century. Coinciding with Roman resistance to the exarch's interference, however, there is first of all the news that Ravenna, which had earlier sought independence, had been brought back under subjection to the apostolic see in the reign of Donus (676-8);98 Theodore, archbishop of Ravenna, presented himself to the apostolic see shortly afterwards. ${ }^{99}$ The reference in the Life of Leo II to an imperial mandate being received to restore Ravenna to Roman control is made to look like an attempt four years later on the part of the emperor in Constantinople to claim the credit and ultimate authority for this change. ${ }^{100}$ This is all the more interesting if one recalls the mosaic of the same Emperor Constantine handing the privilege of the church of Sant'Apollinare in Classe to Archbishop Reparatus or Maurus, apparently commissioned at precisely the time Ravenna returned to Roman jurisdiction. Agnellus of Ravenna presents a very different perception of the relationship between Ravenna and Rome. ${ }^{101}$

In Rome itself, liturgical developments, the building, embellishment and repair of churches and monasteries, the care of the poor, the extolling of papal virtues, the increased provision for the clergy in the form of stipends and bequests, and the growth in papal estates documented by the Liber pontificalis authors, ${ }^{102}$ all served to enhance the pope's authority as bishop. That his authority was not confined to Rome, moreover, is suggested neatly by the record of John IV's redemption of Dalmatian captives, the re-establishment of Rome's ecclesiastical jurisdiction over Ravenna confirmed under Leo II already mentioned and the consecration by Sergius I of Damian as archbishop of Ravenna, Beorhtwald as archbishop 'of

\footnotetext{
97 LP I, Life 90, c. 10, 392; see Gantner, Freunde Roms (above, n. 1), 64-5 and above, p. 253 n. 43.

98 LP I, Life 80, c. 2, 348.

99 LP I, Life 81, c. $1,350$.

100 LP I, Life 82, c. 4, 360; compare also Life 90, c. 9, 391.

101 See D. Mauskopf Deliyannis, Ravenna in Late Antiquity (Cambridge, 2014), 272, 283-4.

102 Aspects of all of these of course have been discussed, for example, T.F.X. Noble, The Republic of St Peter: The Birth of the Papal State, 680-825 (Philadelphia, 1984); J.M.H. Smith (ed.), Early Medieval Rome and the Christian West: Essays in Honour of Donald A. Bullough (Leiden, 2000); Roma nell'alto Medioevo (Settimane di Studio del Centro Italiano di Studi sull'alto Medioevo 48), 2 vols (Spoleto, 2001); Roma fra Oriente e Occidente (Settimane di Studio del Centro Italiano di Studi sull'alto Medioevo 49), 2 vols (Spoleto, 2002); K. Sessa, The Formation of Papal Authority in Late Antique Italy: Roman Bishops and the Domestic Sphere (Cambridge, 2012); J.F. Romano, Liturgy and Society in Early Medieval Rome (Farnham, 2014); Thomas F.X. Noble, 'A court without courtiers: the Roman Church in late antiquity and the early Middle Ages', in Le Corti nell'alto medioevo (Settimane di Studio del Centro Italiano di Studi sull'alto Medioevo 62), 2 vols (Spoleto, 2014), I, 235-57. Nevertheless, a great deal of work from the Roman perspective remains to be done.
} 
Britain' (Britanniae), Clemens (that is, Willibrord) as archbishop for the Frisians, and the consecration of the bishop of Pavia despite the claims from Milan. ${ }^{103}$

If we envisage the Liber pontificalis authors beginning in the middle of the seventh century to assemble material to fill in the eighty years between the Gothic Wars and the time of Honorius, then these authors may themselves have been trying to make sense of fragments of information, inadequate records and contrary indications in order to make specific points about the political position of a pontiff. In doing so they endeavoured to resume the earlier section's (I Peter to Agapetus) concentration on details about the popes. The particular themes emerging from the twelve accounts of papal reigns between the middle of the sixth century and the fourth decade of the seventh century in the 'first continuation' nevertheless appear to be determined more by the seventh-century perspectives and selective recording of the authors. If the first continuation is considered as a prefatory section composed to introduce the themes of what I have labelled as the second and third continuations, this reinforces the possibility that the entire seventh- and early eighth-century portion was put together to form a new extended Liber pontificalis for circulation as an argument, framed as an historical narrative, to support the doctrinal leadership and new political position of the popes.

I have suggested that production of the Liber pontificalis was first resumed at about the same time as the preparations for the Lateran Council of 649 were being made. The completion of the first and second continuations, however, may need to be seen in the context of the preparations for the Sixth Oecumenical Council convened in Constantinople and Pope Agatho's definitive contribution thereto. The subsequent Lives of the popes up to 715 contribute substantially to our understanding of the arguments between Byzantium and Rome. The themes outlined in Lives 60-71 and Roman perspectives emerge ever more forcefully in the remaining Lives 72-90, from Honorius to Constantine I, in the third continuation. I suggest that this culmination of the Liber pontificalis' argument was completed early in the reign of Pope Gregory II (715-31). The popes energetically upheld orthodox doctrine in the face of severe opposition and aggression from Constantinople, centred on monothelitism. These doctrinal disputes definitively undermined the emperor's position in relation to the pope. The mandates concerning the pope's election, candidature and informing the emperor of the new candidate's election all appear to have been part of the orchestration of diplomacy and are not presented in the Roman sources as claims with any real purchase. Imperial intervention is not presented as actually necessary either as validation or as confirmation of papal legitimacy in Rome, whatever the perception in Constantinople. The creation of this version of papal history and the assertion of the pope's position within Rome is thus a remarkable instance of a very concentrated political discourse in historiographical form.

${ }^{103}$ LP I, Lives 74, c. 16,330 ; 82, c. 4, 360; 86, c. 16, 376; 90, c. 9, 391-2. 
For such historiographical discourse to be effective, of course, it needed an audience. In the final section of this paper, therefore, I turn to a consideration of what the extant manuscript evidence may suggest both about this audience and in support of the possible dates of composition and compilation. The Liber pontificalis' dissemination may also shed light on the impulses governing the text's production and its function.

\section{THE CONTINUATIONS OF THE LIBER PONTIFICALIS: COMPOSITION AND DISSEMINATION}

Duchesne discerned possible breaks in the text of the Liber pontificalis between the Lives of Eugenius I and Vitalian (that is, before 672) and between Adeodatus and Donus (that is, 676-8), suggested by notes possibly retained from earlier exemplars in two eleventh-century Italian copies of the text, Vienna Österreichische Nationalbibliothek Cod. 632 and Biblioteca Apostolica Vaticana Vat. lat. 3764.104 To these we can add another possible break between Life 81 of Agatho and Life 82 of Leo II. The text of the latter provides the sequel to the acts of the synod described in the former, for it says that Leo received the acts of the Sixth Council and had them translated into Latin. The author then adds a summary of the Sixth Oecumenical Council as if there had not already been a full account offered in the Life of Agatho. Life 82 also adds Honorius' name to those condemned. Whereas the Life of Agatho had said that the Syriac monks were committed to monasteries in Rome, the Life of Leo II merely says that they were 'confined in various monasteries', though later in the text it is clear that this was in Rome. Life 82 , therefore, has the character of the beginning of a new section, the third continuation, probably disseminated shortly after 715 .

The manuscript transmission of the Liber pontificalis is notoriously unhelpful in charting the text's dissemination before the end of the eighth century. Davis offers the neatest summary of the situation when he states that 'our surviving MSS are all copies of on-going texts which left Rome at different dates and therefore ended at different points. The earlier the text left Rome, the longer the opportunities for its diffusion.' ${ }^{105}$ There is some support, nevertheless, for a late seventh-century or early eighth-century dissemination of the original portion of the Liber pontificalis from the 530s, with the addition of the first and second continuations, in the form of the earliest manuscript of the second edition of the Liber pontificalis. This is a fragment in Naples dating from the late 680s, Naples Biblioteca Nazionale MS IV.A.8 (fols 40-7), written in a North Italian pre-Caroline minuscule dated s. VII/VIII. It is the upper script of a palimpsest: the lower text is an uncial s. VI text. Only four bifolia survive. The leaves

104 Duchesne, Etude (above, n. 6), 205-6.

105 Davis, Eighth-Century Popes (above, n. 13), xiv. 
measure $290 \times 240 \mathrm{~mm}(260 \times 190 \mathrm{~mm})$ but cram the text into two columns of 40-6 lines of text. The fragment includes a list of popes ending with Conon (†687) and the palaeography is compatible with dating the manuscript around this time, presumably during the reign of Sergius I.

The 'Cononian epitome', extant only in later Frankish manuscripts, constitutes a further indication of a dissemination of the Liber pontificalis from Rome in the 680s, by which time, in Davis' opinion, the tradition had already been bifurcated. ${ }^{106}$ That there was thereafter a further dissemination from Rome early in the reign of Gregory II of a version of the Liber pontificalis which went up to the Life of Constantine I is indicated by Lucca, Biblioteca Feliciana MS 490. In this codex there is a clear break after Pope Constantine I, with the following Lives on separately numbered quires and in a different hand. ${ }^{107}$

These meagre clues might indicate that the Liber pontificalis up to and including Life 81 of Agatho was compiled in the early 680s, bearing in mind also the vacancy in the see of one year, seven months and five days that Agatho's Life records before Leo II was consecrated bishop. Some of the details in Agatho's life, moreover, are exceptionally vivid. The account of the synod for the most part reads like a report brought back to Rome, with telling exaggerations and even inventions of someone embroidering their story for dramatic effect such as the 'jet black spider webs falling among the people' (tante tele aranearum nigrissime in medio populi ceciderunt) as an indication of the expelling of the 'filth of heresies' (sordes hereseum). ${ }^{108}$

There are also important connections between the clerics and archive material mentioned in the group of Lives up to and including Agatho and from Leo II to Constantine I. In the entry for John V in particular the author makes a point of referring back to an earlier decision of Pope Martin relating to an ordination of a bishop in Turris by the archbishop of Caralis, and to the documents relating to John V's resolution of the dispute held in the archives. ${ }^{109}$ As already noted, the Liber pontificalis itself records the link between Agatho and later popes, by mentioning among his legates John the deacon, later Pope John V (685-6); Theodore, a priest at the time but subsequently a gracefully retreating candidate for the papal throne in the disputed elections of both Conon (when he was the army's preferred candidate) and Sergius (by which time Theodore had become the archpriest); and Constantine, sub-deacon and later pope, Constantine I. That the 'bonding' between the legates was strong and lasting is further

${ }^{106}$ LP I, lv-lvii, Davis, xlviii and McKitterick, 'Cononian recension' (above, n. 81).

107 See Duchesne, Etude (above, n. 6), 47, who notes the perplexing calculation on the last page of Constantine's Life: Hucusque CXXVIIII anni sunt quod langobardi venerunt et VII menses; this date would give 697 not 715, and Duchesne conjectured it might have been carried over from another exemplar. Still the fullest study is L. Schiaparelli, Il codice 490 della Biblioteca Capitolare di Lucca e la scuola scrittoria Lucchese, sec. VIII-IX (Rome, 1924), but see also the valuable analysis of G.E. Unfer Verre, 'Ancora sul manoscritto 490. Precisazioni e problemi aperti', Rivista di Storia del Cristianesimo 10 (2013), 49-64.

${ }^{108}$ LP I, Life 81, c. 13, 354; trans. Davis, 75.

109 LP I, Life 84, cc. 2 and 4, 366. 
suggested by the depiction, if the identification is valid, of the priest George, another member of the group who went to Constantinople in 680, together with Theodore and possibly the same Pope Constantine, in the recently discovered fresco in the narthex of Santa Sabina in Rome. ${ }^{110}$

Given the legates' subsequent positions as papal officials in the Lateran, it is conceivable that one or more of them was responsible for some parts of these continuations of the Liber pontificalis, or at least contributed to the information the narrative contains. But the crucial importance of the Sixth Oecumenical Council and the intervention of the popes from Martin to Agatho, so clearly presented as the culmination of discussions precipitated by Pope Theodore and the Lateran Synod presided over by Pope Martin of 649, and a reiteration of the insistence on Chalcedonian orthodoxy since the time of Pope Leo I, suggest that these events were indeed the inspiration for the resumption and continuation of the Liber pontificalis. The text was part of the pope's arsenal. It needs to be seen in the same context, and as part of the same creative endeavour, as the circulation of the Latin texts of the Councils of both 649 and 680 in the West. All these emanated from Rome.

There are, for instance, some indications of the close connection between the reproduction of the Latin translations of the Councils of the Lateran (649) and Constantinople (680). Rudolf Riedinger suggested that the significant correspondences between the Latin translation of the revised version of Lateran 649 and papal letters from the 680s were to be credited to bilingual papal officials, though this has been questioned by Richard Pollard and by Richard Price, who make a case for the translation and letter-composition by native Romans. ${ }^{111}$ Later seventh-century Rome was clearly at fever pitch for the production of texts insisting on the orthodox position of Rome and papal leadership of the church.

It is significant that one of the earliest manuscripts of the Latin text of the decrees of Lateran 649 was written at the monastery of Saint Amand, the foundation of Amandus, bishop of Maastricht. The manuscript is now in Laon, Bibliothèque Municipale MS 199, and dated 820-40. Earlier witnesses survive in Bern, Burgerbibliothek MSS A56 and A55 from Orleans, dated 800-20, and

${ }^{110}$ LP I, Life 81, c. 3, 350. M. Gianandrea, 'Nel lusso della tradizione. L'inedita nel nartece di Santa Sabina all'Aventino a Roma (Il nartece di Santa Sabina, 1)', Hortus Artium Medievalium 20 (2014), 700-8; J. Osborne, 'Rome and Constantinople about the year 700: the significance of the recently uncovered mural in the narthex of Santa Sabina', in G. Bordi, I. Carlettini, M.L. Fobelli, M.R. Menn and P. Pogliani (eds), L'Officina delle sguardo. Scritti in onore de Maria Andaloro (Rome, 2015), 329-34; M. Gianandrea, 'Politica delle immagini al tempo di papa Costantino 708-715: Roma versus Bisanzio', in Bordi, Carlettini, Fobelli, Menn and Pogliani (eds), L'Officina delle sguardo (above), 335-42. For an alternative identification see McKitterick, 'The damnatio memoriae of Pope Constantine II (above, n. 16).

111 R. Riedinger, Acta Conciliorum Oecumenicorum, series 2.1: Concilium Lateranense a. 649 celebratum (Berlin, 1984), xiv; R. Price, 'The letter to Bishop Amandus', in Price, Booth and Cubitt, The Acts of the Lateran Synod (above, n. 5), 391-3; and Pollard, 'The decline of cursus' (above, n. 11). 
as an extract in Paris, Bibliothèque nationale de France MS lat. 2123, dated 795816. All these were evidently from earlier exemplars. It was to Amandus that Pope Martin addressed a letter, saying he had arranged for a copy of the decrees of Lateran 649 to be despatched to him, and urging Amandus to get the Frankish bishops to approve the decrees and even to persuade King Sigibert of Austrasia to send a delegation of Frankish bishops to Constantinople. ${ }^{112}$ It is also to the scriptorium of Saint Amand that a late eighth- or early ninth-century copy of the Liber pontificalis running to Life 94, Leiden Universiteitsbibliotheek Voss. Lat. 60 (at Reims later in the ninth century), is to be credited, as well as the Latin text of the Sixth Oecumenical Council, now in Vienna, Österreichische Nationalbibliothek MS 418, copied at the turn of the eighth century. This too was produced by scribes in the 'Arn-style', though possibly in Salzburg after Bishop Arn (formerly abbot of Saint Amand) had arrived there. ${ }^{113}$ Arn has also been associated with another copy of the Sixth Council's decrees (Bibliotheca Apostolica Vaticana MS reg. lat. 1040), also in 'Arn-style', which was apparently corrected against a Roman exemplar at the end of the eighth century. ${ }^{114}$ It may well be to Arn's own visits to Rome at the end of the eighth century, therefore, that the acquisition of both the Liber pontificalis and Sixth Council texts needs to be attributed, thus augmenting the Lateran 649 texts from Rome already received by Amandus. This conjunction of the Liber pontificalis and the seventh-century synods in Frankish centres of learning and book production as witnesses to late seventh-century reception as well as further dissemination in the ninth century, however, merit fuller investigation than I can undertake here.

Another important witness to the reception of these texts from and direct contact with Rome is Bede in Anglo-Saxon England. Bede shows indisputable knowledge of the Liber pontificalis, for he cites it directly in both the Historia ecclesiastica written c. 731 and his earlier 'World Chronicle' (c. 66 of the De temporum ratione), written by 725 .

As far as the Historia ecclesiastica is concerned, reference has already been made to the interpretation Bede put on the consecration of the Pantheon under Pope Boniface IV, for example, and Bede also took his notes of the visit of Lucius, king of Britain, some details from the Life of Gregory I, an observation about a comet in the Life of Donus, and the death of Cenred and Offa recorded in the Life of Constantine I, from the Liber pontificalis. ${ }^{115}$ But there is also Bede's report that Theodore had been sent to Canterbury as archbishop by

112 Price, 'The letter to Bishop Amandus' (above, n. 110), 408-12.

113 R. Riedinger, Acta Conciliorum Oecumenicorum, series 2.2 part 1 (Berlin, 1990), xiv. Compare B. Bischoff, Die südostdeutschen Schreibschulen und Bibliotheken II: Die vorwiegend Österreichischen Diözesen (Wiesbaden, 1980), 125-6.

114 Bischoff, Die südostdeutschen Schreibschulen (above, n. 112), 64.

115 Bede, Historia ecclesiastica (above, n. 49), II.4, p. 148; I.4, p. 24; II.1, pp. 122 and 130; V.19, p. 516. 
Pope Vitalian. This is not noted in the Life of Vitalian. ${ }^{116}$ Theodore, who had been a prominent member of the Roman clergy under Pope Vitalian, convened the Synod of Haethfeld in 679. Bede adds the information that John the Archcantor had returned from Rome with the decisions of Pope Martin's synod condemning the monothelite heresy. ${ }^{117}$ The English bishops at Haethfeld affirmed their alignment with Rome's position as stated in the Lateran Council of 749 and the first five oecumenical councils. ${ }^{118}$

In the 'World Chronicle', Bede refers on a number of occasions to events in Rome. Even more telling is his report from Pope Constantine I's Life that Anastasius had sent letters to Pope Constantine affirming his support of the decrees of the Council of 680/1.119 This suggests that a text of the Liber pontificalis compiled no later than early in the reign of Gregory II, and containing the Lives up to AD 715, had reached England in the second decade of the eighth century, and that its insistence on orthodoxy and the supreme achievement of the pope had been fully registered.

\section{CONCLUSION}

The seventh and early eighth-century portions, that is, Lives 60-90, of the Liber pontificalis form a distinct unit, albeit composed in stages and with occasional inconsistencies, and with a clear agenda to maintain the particular representation of the history of Christian Rome and the popes that distinguished the original section. The later sections, that is, the first, second and third continuations, were specifically designed to assert a particular position in relation to the upholding of the orthodox Christian faith and the pope's role within the church, within Rome, and as a rival to Byzantium. The extant manuscript evidence, thin and problematic as it undoubtedly is, suggests an energetic dissemination of this particular representation of the popes far beyond Rome. The Liber pontificalis was thus in the position to be the powerful and influential text on which Frankish, English and even Byzantine knowledge and understanding of the popes and of their championing of

116 Bede, Historia ecclesiastica (above, n. 49), IV.1, pp. 328-32.
117 Bede, Historia ecclesiastica (above, n. 49), IV.17-18, pp. 384-90.
118 On Theodore and the Synod of Hatfield see Noble, 'Rome in the seventh century' (above, n. 5) and H. Chadwick, 'Theodore, the English church and the monothelite controversy', in Lapidge (ed.), Archbishop Theodore (above, n. 5), 68-87 and 88-95 respectively; and C. Cubitt, Anglo-Saxon Church Councils c. 650-c. 850 (Leicester, 1985), 252-8. Incidentally, this synod also affirmed the double procession of the holy spirit: on the filioque discussions culminating in the Carolingian wish to include filioque in the Creed see R. McKitterick, Charlemagne: The Formation of a European Identity (Cambridge, 2008), 311-15 and A.E. Siecienski, The Filioque: History of a Doctrinal Controversy (Oxford, 2010).

119 Bede, De temporum ratione, ed. Mommsen (above, n. 23), 324. Compare F. Wallis, Bede: the Reckoning of Time (Translated Texts for Historians) (Liverpool, 1999), who identifies Bede's debts to the Liber pontificalis in the footnotes to her translation. 
orthodox doctrine was based. That knowledge underpinned the developments in the religious and political spheres in the course of the eighth century. ${ }^{120}$

One point remains to be stressed: knowledge in the early Middle Ages not only of the principal decisions of both Lateran 649 and Constantinople 680/1, but also of the pope's leadership of both, could be derived very well from the Liber pontificalis alone. This was surely the authors' intention. Yet the Liber pontificalis provided more than a narrative means for the conveyance of doctrinal positions; it was the fundamental vehicle for the articulation and communication of the new role of the pope and of Rome in the West in the early Middle Ages.

Address for correspondence:

Professor Rosamond McKitterick

Faculty of History, University of Cambridge, West Road, Cambridge, CB3 9EF, United Kingdom. rdm21@cam.ac.uk

\section{Acknowledgements}

I should like to thank the Editor of the PBSR, Mark Bradley, and the two anonymous readers of this article for their very helpful criticisms and constructive suggestions, and Iveta Adams for her meticulous assistance in preparing the text for publication.

${ }^{120}$ For recent work on aspects of this see T.F.X. Noble, Images, Iconoclasm, and the Carolingians (Philadelphia, 2009) and M.T.G. Humphreys, Law, Power, and Imperial Ideology in the Iconoclast Era, c. 650-850 (Oxford, 2015). 